\title{
A new resource to study the health of military families in Ontario
}

\author{
Alyson L. Mahar, Alice B. Aiken, Heidi Cramm, Patti Groome, Paul Kurdyak
}

Accessing health care and maintaining continuity of care during mandatory moves remains a persistent challenge for military families. ${ }^{1,2}$ The re-establishment of medical services is the number one concern of military spouses for a new posting. ${ }^{2,3}$ In Canada, there is little population-based data on the health and health services utilization of military families, making it difficult to understand the health issues they experience. For the first time, we have identified a method of studying the health of military families in Ontario. Data are gathered from existing provincial administrative health care data sets housed at the Institute for Clinical Evaluative Sciences (ICES) and linked to administrative codes for provincial health care collected by the Ontario Ministry of Health and Long-Term Care. The following is a brief introduction to the variables available in this new resource, and its potential uses for future research.

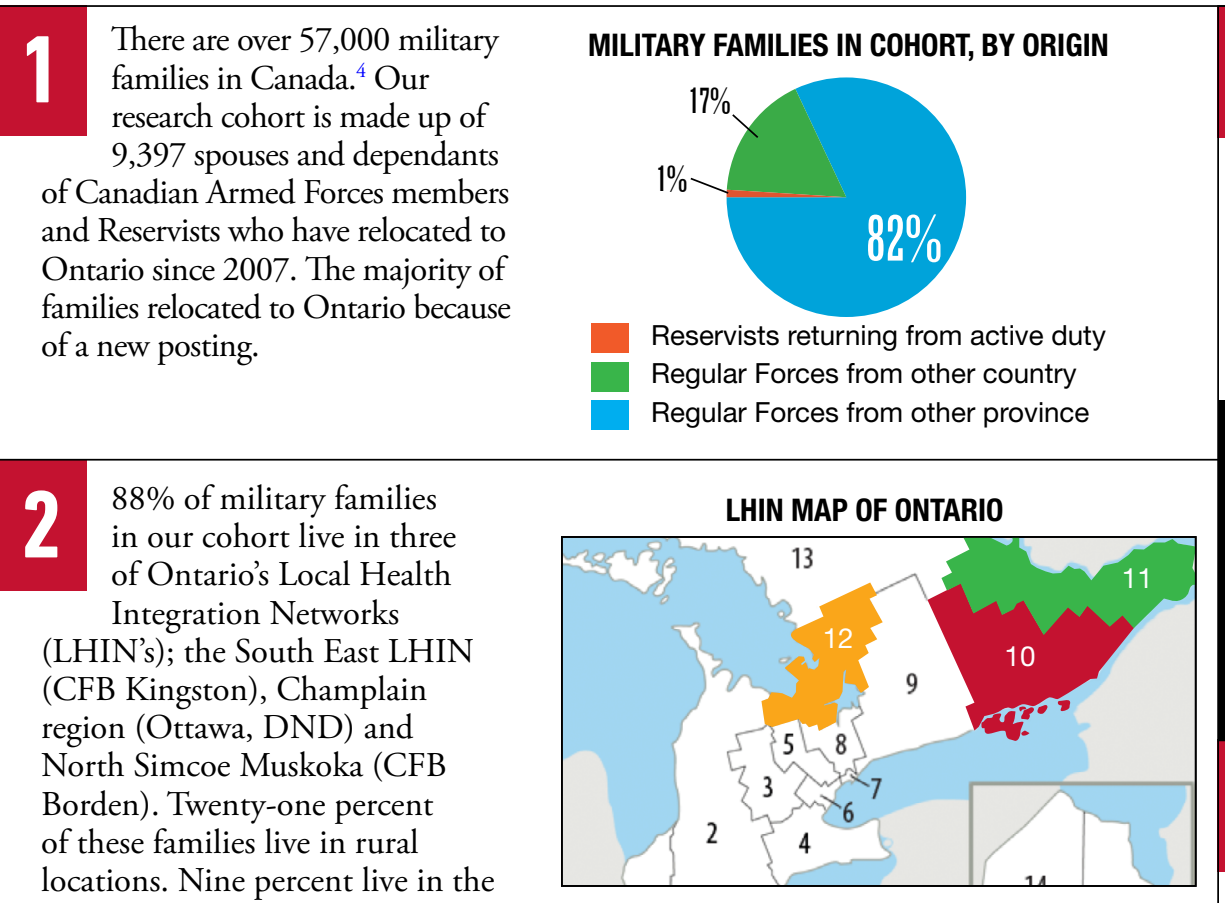
lowest income communities.
10 South East 11 Champlain 12 North Simcoe

\section{With these data, we will be 0 able to study the prevalence of physical and mental disorders, their treatment, and compare outcomes to civilian families.}

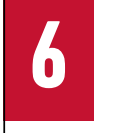

The health services utilization data will allow us to study continuity of care and identify potential gaps in the provision of healthcare for military families.

\section{HEART DISEASE ASTHMA • STROKE DIABETES • GANGER MENTAL HEALTH RNURIES}

\section{FAMILY PHYYSIGIAN VISIIS}

SPECIALIST PHYSICIAN VISITS

EMERGENOY DEPARTMENT VISIIS

HOSPITAL ADMISSIONS PSTGHATRIG ADMISSIONS
20\% of our research $\checkmark$ cohort are dependents (age $\leq 18$ years). The median age of the dependents in the cohort is 7 years (IQR: 3-12 years). The proportion of female to male dependents in the cohort is roughly equal (49\% female).

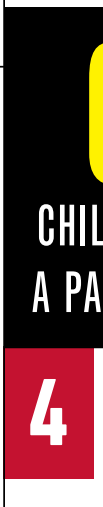

Approximately 13\% of all military spouses in Canada are male. ${ }^{4}$ Our cohort has a smaller proportion of male spouses than expected. The median age of military spouses in our cohort is 35 years (IQR: 29-42 years).

\section{CIVILIAN SPOUSES IN COHORT}

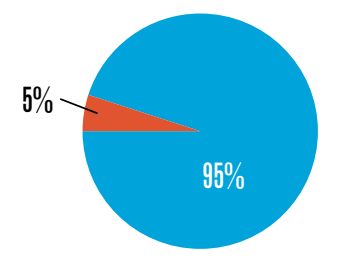

Women Men

Understanding how relocations impact the continuity of care and health of military families will provide a baseline to study interventions targeted at facilitating access to primary and specialist healthcare and system navigation for military families in the future. 


\section{REFERENCES}

1. Dar W, Doan B; Department of National Defence.An examination of Canadian Forces spouses' access to a family physician. 2011. Available from: https://www. cfmws.com/en/AboutUs/MFS/FamilyResearch/Pages/ default.aspx

2. National Defense and The Canadian Armed Forces Ombudsman. On the homefront: assessing the wellbeing of Canada's military families in the new millennium. 2013. Available from: http://www.ombudsman. forces.gc.ca/en/ombudsman-reports-stats-investigations-military-families/military-families-index.page

\section{AUTHOR INFORMATION}

Alyson L. Mahar, MSc is a PhD Candidate in the Department of Public Health Sciences at Queen's University, Kingston, ON.

Alice Aiken, $\mathrm{CD}, \mathrm{PhD}$ is an Associate Professor and Associate Director of the School of Rehabilitation Therapy (Physical Therapy Program) at Queen's University, Kingston, $\mathrm{ON}$, and the Director of the Canadian Institute for Military and Veteran Health Research.

Heidi Cramm, PhD, OT is an Assistant professor in the School of Rehabilitation Therapy at Queen's University and the Head of Knowledge Translation in the Canadian Institute for Military and Veteran Health Research.

Patti Groome, is a Senior Scientist in the Division of Cancer Care and Epidemiology at the Queen's Cancer Research Institute, a Professor in the Department of Public Health Sciences at Queen's University, Kingston, ON, and an Institute for Clinical Evaluative Sciences (ICES) Scientist, at Queen's and ICES Toronto, ON.

Paul Kurdyak, MD, PhD, is the Director of Health Systems Research at the Centre for Addiction and Mental Health, Toronto, ON, an Assistant Professor in the Department of Psychiatry at The University of Toronto, and an an Institute for Clinical Evaluative Sciences Scientist and Program Lead at ICES Toronto, ON

Correspondence should be addressed to Alyson Mahar at: alyson.mahar@queensu.ca
3. Dursun S, Skomorovsky A. Military family research: challenges facing military families. Lecture presented through CIMVHR webinar hosted at The Royal Military College of Canada. Kingston, 2012 Sep 22.

4. Vanier Institute for the Family. Military families by the numbers. 2012. Available from: http://www.vanierinstitute.ca/modules $/$ news $/$ newsitem.php?ItemId $=472$

\section{COMPETING INTERESTS}

None declared.

\section{DISCLAIMER}

The opinions, results and conclusions reported in this paper are those of the authors and are independent from the funding sources. No endorsement by ICES or the Ontario MOHLTC is intended or should be inferred.

\section{CONTRIBUTORS}

All authors conceived, designed, researched, and drafted the manuscript and approved the final version submitted for publication.

\section{FUNDING}

This study was funded by a donation from the True Patriot Love Foundation, a donation from Queen's Medical School Class of 2017 in the memory of Sgt Doiron, and by the Queen's University Research Initiation Fund. In addition, this study was also supported by the Institute for Clinical Evaluative Sciences (ICES), which is funded by an annual grant from the Ontario Ministry of Health and Long-Term Care (MOHLTC).

Graphics conceived, designed and illustrated by Mike Schaub and Brock Ostrom. 